\title{
Induction of Myeloid-Derived Suppressor Cells in Cryopyrin-Associated Periodic Syndromes
}

\author{
Marlene Ballbach ${ }^{a}$ Tobias Hall ${ }^{a}$ Alina Brand ${ }^{a}$ Davide Neri ${ }^{a} \quad$ Anurag Singh $^{a}$ \\ Iris Schaefer $^{a}$ Eva Herrmann ${ }^{b}$ Sandra Hansmann ${ }^{a}$ Rupert Handgretinger ${ }^{a}$ \\ Jasmin Kuemmerle-Deschner ${ }^{\mathrm{a}}$ Dominik Hartl ${ }^{\mathrm{a}}$ Nikolaus Rieber ${ }^{\mathrm{a}, \mathrm{c}}$ \\ ${ }^{a}$ Department of Pediatrics I, University of Tübingen, Tübingen, ${ }^{b}$ Department of Biostatistics and \\ Mathematical Modelling, University of Frankfurt, Frankfurt am Main, and ' ${ }^{\mathrm{D}}$ Department of Pediatrics, \\ Kinderklinik München Schwabing, Klinikum Schwabing, StKM GmbH und Klinikum rechts der Isar, \\ Technische Universität München, Munich, Germany
}

\section{Key Words}

Myeloid-derived suppressor cells · Neutrophils .

Autoinflammation - NLRP3 - Cryopyrin-associated periodic syndrome $\cdot$ IL-1 $\beta$. Chemokines · Growth factors

\begin{abstract}
Cryopyrin-associated periodic syndromes (CAPS) are caused by mutations in the NLRP3 gene leading to overproduction of IL- $1 \beta$ and other NLRP3 inflammasome products. Myeloidderived suppressor cells (MDSCs) represent a novel innate immune cell subset capable of suppressing T-cell responses. As inflammasome products were previously found to induce MDSCs, we hypothesized that NLRP3 inflammasome-dependent factors induce the generation of MDSCs in CAPS. We studied neutrophilic MDSCs, their clinical relevance, and MDSC-inducing factors in a unique cohort of CAPS patients under anti-IL-1 therapy. Despite anti-IL-1 therapy and low clinical disease activity, CAPS patients showed significantly elevated MDSCs compared to healthy controls. MDSCs were functionally competent, as they suppressed polyclonal T-cell proliferation, as well as Th1 and Th17 responses. In addition,
\end{abstract}

MDSCs decreased monocytic IL-1 $\beta$ secretion. Multiplex assays revealed a distinct pattern of MDSC-inducing cytokines, chemokines, and growth factors. Experimental analyses demonstrated that IL-1 cytokine family members and autoinflammation-associated alarmins differentially induced human MDSCs. Increased MDSCs might represent a novel autologous anti-inflammatory mechanism in autoinflammatory conditions and may serve as a future therapeutic target.

(c) 2016 S. Karger AG, Basel

\section{Introduction}

The cryopyrin-associated periodic syndromes (CAPS) comprise a spectrum of autoinflammatory diseases, including FCAS (familial cold-induced autoinflammatory syndrome), through MWS (Muckle-Wells syndrome), to NOMID (neonatal-onset multisystem inflammatory disease), also known as CINCA (chronic infantile neurological, cutaneous, articular) syndrome [1]. These disease conditions are characterized by recurrent episodes of systemic inflammation marked by fever, tissue inflamma-

\section{KARGER}

E-Mail karger@karger.com

www.karger.com/jin
(C) 2016 S. Karger AG, Basel

1662-811X/16/0085-0493\$39.50/0
Dr. Nikolaus Rieber or Dr. Dominik Hart

Department of Pediatrics I, University of Tübingen

Hoppe-Seyler-Str. 1

DE-72076 Tübingen (Germany)

E-Mail nikolaus.rieber@med.uni-tuebingen.de or dominik.hartl@ med.uni-tuebingen.de 
tion (particularly of the joints and skin), urticarial rash, and sensorineural hearing loss [2]. CAPS are caused by mutations in the NLRP3 (Nod-like receptor family, pyrin domain containing 3 ) gene encoding the cryopyrin protein, a key component of the NLRP3 inflammasome that activates caspase-1, resulting in inflammation driven by excessive secretion of the cytokine IL-1 $\beta$ [3-6]. Disease causing mutations in the NLRP3 gene together with the typical symptoms are an indication for a continuous antiIL-1 therapy to prevent long-term sequelae, such as kidney failure or hearing loss [7].

The physiologically occurring IL-1 receptor antagonist (IL-1RA) is highly increased in active CAPS patients, pointing to an autologous anti-inflammatory feedback loop. Up to now there have been no reports on cellular anti-inflammatory mechanisms operative in CAPS. However, inflammatory Th17 cells have been reported to be significantly elevated in CAPS [8], providing a rationale to speculate on a counter-regulatory increase of regulatory immune cells in these patients. Myeloid-derived suppressor cells (MDSCs) represent a novel innate immune cell subset generated in tumor, infective, and proinflammatory microenvironments [9-11]. These specialized innate immune cells are characterized by their capacity to suppress T-cell responses and thereby modulate the cellular arm of the adaptive immunity [10]. Consequently, MDSCs are considered to be a key player in the balance between innate and adaptive immune responses, particularly under chronic disease conditions. In mice, where MDSCs have been studied extensively, these cells comprise both a neutrophilic and a monocytic MDSC subphenotype [10,12-14], while studies on MDSCs in human disease conditions other than cancer are scarce. Recent evidence suggests that primarily neutrophilic MDSCs accumulate in malignancy and systemic inflammation [15-17]. The maturation stage of neutrophilic MDSCs is still a matter of debate in the field. While the suppressive phenotype has been linked to an immature state, other concepts define neutrophilic/granulocytic MDSCs as a heterogeneous group of T-cell suppressive immune cells with neutrophilic/granulocytic phenotypes, without a clear demarcation between immature and mature cells [18-21]. In this paper we favor the latter, more general approach regarding the maturity of neutrophilic MDSCs.

As murine studies have provided evidence that the inflammasome induces the generation of MDSCs as innate autologous anti-inflammatory cells [22-24], we hypothesized that MDSCs might play a role in CAPS. Our studies demonstrate for the first time that neutrophilic MDSCs are induced in CAPS patients even under effective anti-
IL-1 therapy and reveal novel MDSC-inducing factors in these patients. Increased MDSCs might represent a novel autologous anti-inflammatory mechanism in autoinflammatory conditions and may serve as a future therapeutic target.

\section{Patients and Methods}

\section{Study Population}

The study was conducted at the University Children's Hospital, Tuebingen (Germany). Informed written consent was obtained from all subjects included in the study (or their legal representatives), and all study methods were approved by the local ethics committee. The study population consisted of 28 CAPS patients (16 females, 12 males) with ages ranging from 3 to 78 years (mean age 32 years). CAPS patients were diagnosed based on their characteristic clinical presentations for CAPS and NLRP3 gene mutations [2]. Clinically, CAPS patients resembled an MWS or MWS/ FCAS overlap phenotype. At the time of blood sampling for MDSC analyses, all CAPS patients received regular anti-IL-1 treatment with canakinumab and were in clinical remission. Control subjects were from 0 to 44 years of age (mean age 14 years), without signs of infections, malignancies, or inflammation at the time of blood sampling. The samples from the children in this control group were taken through a routinely inserted intravenous line before undergoing elective surgery for multiple diagnoses.

\section{Cell Isolation and Flow Cytometry}

Peripheral blood mononuclear cells (PBMCs) were prepared from heparinized blood samples by Ficoll density gradient sedimentation (lymphocyte separation medium; Biochrom) and washed twice in RPMI 1640 medium (Biochrom). Trypan blue staining solution (Sigma-Aldrich) at $0.5 \%$ differentiated between viable and nonviable cells and showed a viability of $>90 \%$ for all cells used in this study. After Ficoll density gradient sedimentation, MDSCs were characterized as $\mathrm{SSC}^{\text {high }} \mathrm{CD} 66 \mathrm{~b}^{\text {high }} \mathrm{CD} 33^{\text {high }}$ CD $16^{\text {high }}$ CXCR $4{ }^{\text {high }}$ HLA-DR ${ }^{\text {low }}$ cells in the PBMC fraction based on previously established human MDSC analysis methods [15, 17] (fig. 1a). PBMCs outside this neutrophilic MDSC population were CD66b negative (online suppl. fig. S1; for all online suppl. material, see www.karger.com/doi/10.1159/000446615). For MDSC isolation, cells were obtained from the PBMC fraction and labeled with anti-CD66b-FITC followed by two sequential anti-FITC magnetic bead separation steps (Miltenyi Biotec), according to the manufacturer's protocol. The purity of $\mathrm{CD} 6 \mathrm{~b}^{+}$cells after separation was $>95 \%$ as assessed by flow cytometry. Conventional neutrophils (polymorphonuclear neutrophils, PMNs) were isolated from the high-density fraction of a Ficoll density gradient sedimentation (lymphocyte separation medium; Biochrom) followed by erythrocyte lysis using ammonium chloride and an additional enrichment step using magnetic bead separation for $\mathrm{CD}^{2} 6 \mathrm{~b}^{+}$, as described above. The morphology of the cells (MDSCs and conventional neutrophils isolated from CAPS patients) was analyzed by May-Grünwald-Giemsa staining of cytospins (fig. 1b). Isolated MDSCs featured typical morphological characteristics of neutrophils, identifying them as neutrophilic MDSCs [25]. Antibodies against CD4, CD8, CD16, and CCR2 were purchased from BioLegend, anti-human CD33 from Miltenyi Biotec, and antibodies 


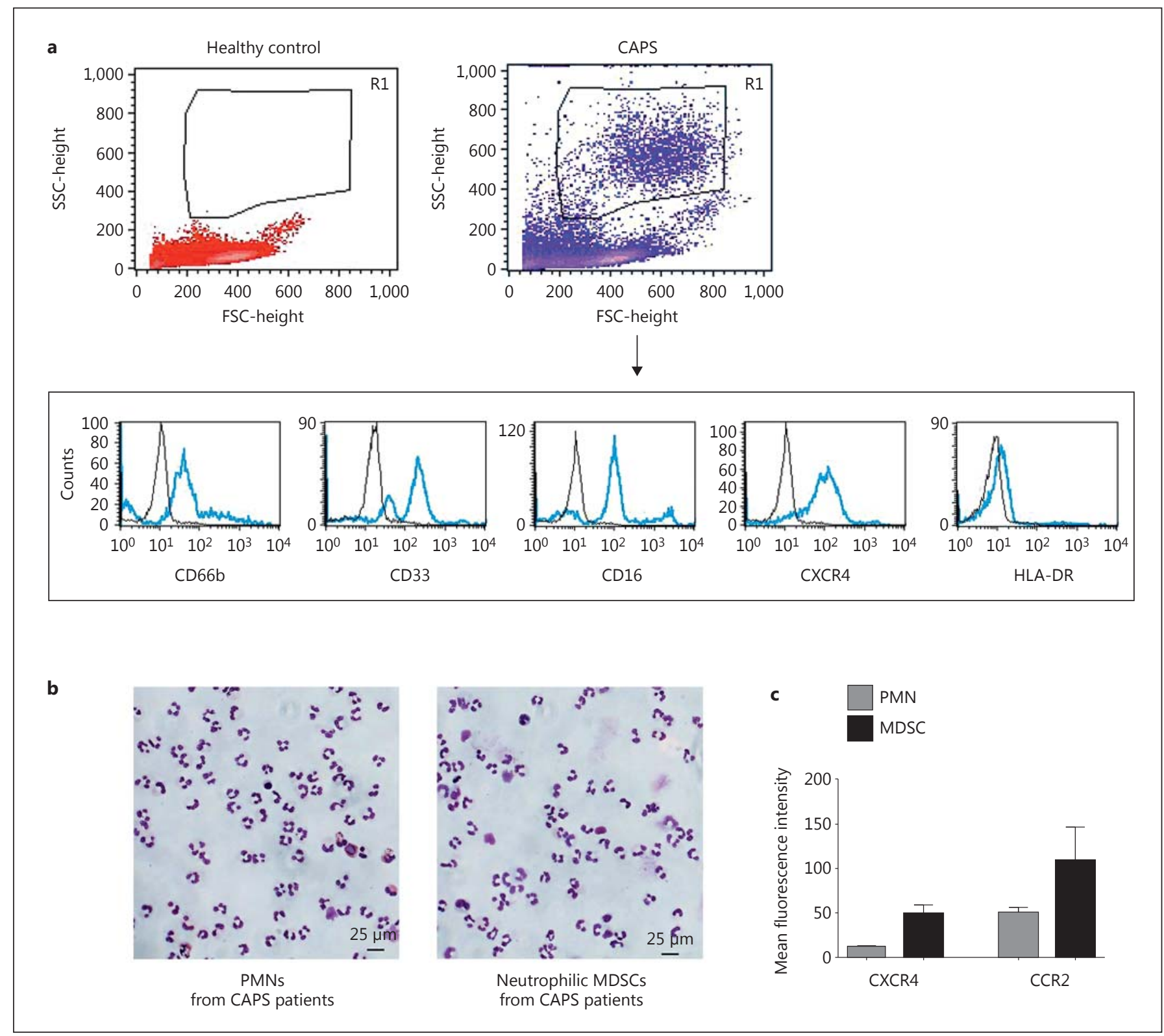

Fig. 1. Phenotypic characterization of MDSCs. PBMCs were isolated from heparinized blood of CAPS patients and healthy agematched controls using Ficoll density gradient sedimentation. a MDSCs were identified by flow cytometry as neutrophilic cells which are $\mathrm{CD} 66 \mathrm{~b}^{\text {high }}, \mathrm{CD} 33^{\text {high }}, \mathrm{CD} 16^{\text {high }}, \mathrm{CXCR} 4^{\text {high }}$, and HLA$\mathrm{DR}^{\text {low }}$, as shown representatively in the FSC-SSC (forward scatter- side scatter) dot blots and histograms. b Representative MayGrünwald-Giemsa-stained cytospins of conventional neutrophils (PMNs) and neutrophilic MDSCs are shown. c Mean fluorescence intensities of chemokine receptors CXCR4 and CCR2 in PMNs and neutrophilic MDSCs were determined by flow cytometry. against CD66b and HLA-DR from BD Pharmingen. Anti-human CXCR4 (clone 12G5) was obtained from eBioscience. Mouse IgG1-FITC, mouse IgM-FITC, mouse IgG1-PE, and mouse IgG1APC (BD Pharmingen) were used as isotype controls. Results were expressed as percentage of positive cells and mean fluorescence intensity. Quantifications were performed with BD CellQuest and
FlowJo (FlowJo, LLC) analysis software. For all in vitro flow cytometry assays at least 3 independent experiments were performed.

In vitro Characterization and Isolation of Human MDSCs

Human MDSCs were characterized in vitro according to a previously published protocol [26]. Isolated human PBMCs from 
healthy controls were cultured in 12-well flat bottom plates (Corning) or $25-\mathrm{cm}^{2}$ flasks (Greiner Bio-One) at $5 \times 10^{5} \mathrm{cells} / \mathrm{ml}$ in RPMI 1640 supplemented with $10 \%$ heat-inactivated FCS (PAA Laboratories), $2 \mathrm{~mm}$ glutamine (Sigma-Aldrich), $100 \mathrm{IU} / \mathrm{ml}$ penicillin, and $100 \mathrm{mg} / \mathrm{ml}$ streptomycin (Biochrom) (subsequently referred to as 'complete medium') for 6 days, and granulocyte-macrophage colony-stimulating factor (GM-CSF, $10 \mathrm{ng} / \mathrm{ml}$; Genzyme), IL-1 $\beta$, IL-1a (both PeproTech), IL-18 (MBL International), IL-33 (GenWay Biotech), S100 proteins (ProSpec), calprotectin (Hycult Biotech), and hybrid serum amyloid A (SAA; PeproTech) were added at different concentrations as indicated in the respective figures. For all assays, at least 3 independent experiments were performed. PBMCs cultured in complete medium alone were run in parallel as a control for each donor. Medium and supplements were refreshed after 3 days. After 6 days, all cells were collected from PBMC cultures. Adherent cells were removed using nonprotease cell detachment solution Detachin (Genlantis). MDSCs were determined as $\mathrm{SSC}^{\text {high }} \mathrm{CD} 33^{+} \mathrm{CD} 14^{-}$cells. The number of MDSCs as a percentage of all cells in medium-only cultures was set to 1 -fold for every single experiment. The MDSC induction due to the specific stimuli is presented as $\mathrm{x}$-fold compared to medium control. For functional assays $\mathrm{CD}_{3} 3^{+}$cells were isolated from each culture using anti-CD33 magnetic microbeads and LS column separation (Miltenyi Biotec) according to the manufacturer's instructions. The purity of isolated cell populations was $>90 \%$, as assessed by flow cytometry. A May-Grünwald-Giemsa-stained cytospin of these isolated $\mathrm{CD} 33^{+}$cells is given in online supplementary figure S3. The complete flowcytometric characterization of surface markers of the in vitro MDSC population is shown in online supplementary figure $\mathrm{S} 4$.

\section{T-Cell Suppression Assay and Cytokine Analysis in}

Supernatants

Responder PBMCs were obtained from healthy volunteers and stained with carboxyfluoresceinsuccinimidyl ester (CFSE) according to the manufacturer's protocol (Invitrogen). PBMCs were stimulated with $100 \mathrm{U} / \mathrm{ml}$ IL-2 (R\&D Systems) and $1 \mu \mathrm{g} / \mathrm{ml}$ antiCD3 antibody (OKT3; Janssen-Cilag). In a standardized way, 60,000 PBMCs per well in RPMI 1640 were seeded in a 96-well microtiter plate, and 10,000-30,000 MDSCs in RPMI 1640 or as control isolated conventional non-MDSC neutrophils in RPMI 1640 or RPMI 1640 only were added. Diphenyleneiodonium chloride (DPI, $1 \mu \mathrm{M}$; Sigma-Aldrich) and $\mathrm{N}^{\mathrm{G}}$-monomethyl-L-arginine (L-NMMA, $0.5 \mathrm{mM}$; Calbiochem) were added where indicated. The cell culture was supplemented with $10 \%$ heat-inactivated human serum, $2 \mathrm{mM}$ glutamine, $100 \mathrm{IU} / \mathrm{ml}$ penicillin, and $100 \mathrm{mg} / \mathrm{ml}$ streptomycin. After $96 \mathrm{~h}$ of incubation in a humidified atmosphere at $37^{\circ} \mathrm{C}$ and $5 \% \mathrm{CO}_{2}$, the cells were harvested and supernatants were frozen at $-20^{\circ} \mathrm{C}$. CD $4^{+}$or $\mathrm{CD} 8^{+} \mathrm{T}$ cells, respectively, were gated and analyzed for CFSE dilution to determine polyclonal $\mathrm{T}$ cell proliferation. Only propidium iodide (PI)-negative cells were considered for analysis. Supernatants of the cocultures were taken to perform an IFN $\gamma$ ELISA (R\&D Systems) and a multiplex cytokine array (Bio-Plex Pro human cytokine array; Bio-Rad Laboratories) according to the manufacturers' protocols.

Suppression of IL-1 $\beta$ Secretion

$\mathrm{CD} 6 \mathrm{~b}^{+}$MDSCs from heparinized blood of CAPS patients were isolated, as described above. $\mathrm{CD} 14^{+}$cells were isolated from the $\mathrm{CD} 6 \mathrm{~b}^{-} \mathrm{PBMC}$ fraction using anti-CD14 magnetic micro- beads and LS column separation (Miltenyi Biotec). CD14 ${ }^{+}$cells were seeded in a 1:1 ratio with $\mathrm{CD} 6 \mathrm{~b}^{+}$MDSCs or with complete medium only and left unstimulated or were stimulated with $10 \mathrm{ng} /$ $\mathrm{ml}$ LPS (Sigma-Aldrich) [27]. After $4 \mathrm{~h}$ of incubation in complete medium at $37^{\circ} \mathrm{C}$ and $5 \% \mathrm{CO}_{2}$, supernatants were taken and IL- $1 \beta$ secretion of $\mathrm{CD} 14^{+}$monocytes was measured by an IL- $1 \beta$ ELISA (R\&D Systems) according to the manufacturer's protocol. Conventional $\mathrm{CD} 6 \mathrm{~b}^{+}$neutrophils were run in parallel as control.

\section{Cytokine Analysis in Serum}

Multiplex cytokine array analysis in sera of CAPS patients before and 4 weeks after the start of anti-IL-1 therapy with canakinum$\mathrm{ab}$ and of controls was performed using the Bio-Plex protein multiarray system (Bio-Plex Pro human cytokine array; Bio-Rad Laboratories). For the current experiments, a human 27-plex assay was used according to the recommendations of the manufacturer (Bio$\mathrm{Rad})$.

\section{Statistical Analysis}

Data are reported as means \pm SEM. Differences between the control group and patients were analyzed by an unpaired t test assuming Gaussian distribution or a Mann-Whitney test assuming non-Gaussian distribution. Differences between different conditions within the patient cohort were analyzed by a paired t test assuming Gaussian distribution or a Wilcoxon test assuming nonGaussian distribution. Differences between stimulants and medium control were analyzed by a one-sample t test. Correlations are described with Spearman's correlation coefficient $r$. Statistical tests were calculated using Prism 6.01 software (GraphPad Software). In all tests, differences were considered significant at $\mathrm{p}<$ 0.05 .

\section{Results}

Neutrophilic MDSCs Are Increased in CAPS Patients

In a large CAPS patient cohort $(\mathrm{n}=28)$, percentages of neutrophilic MDSCs were significantly increased compared to age-matched healthy control subjects $(n=36$; $\mathrm{p}<0.0001$; fig. 2a). When compared to conventional neutrophils these neutrophilic MDSCs from the Ficoll lowdensity fraction (see Patients and Methods) showed the typical nuclear morphology of neutrophils and expressed the characteristic neutrophilic surface markers CD66b and CD16, but displayed increased expression of chemokine receptors CXCR4 and CCR2 (fig. 1), as reported previously $[17,28,29]$. All CAPS patients were under antiIL-1 therapy with canakinumab and in clinical remission or had minimal residual disease activity at the time of blood sampling. We did not detect a significant correlation of neutrophilic MDSCs with common laboratory inflammation markers, namely ESR, CRP, and SAA (fig. 2b). However, with few exceptions, the values of these inflammation markers were within normal limits at the time of blood sampling. 


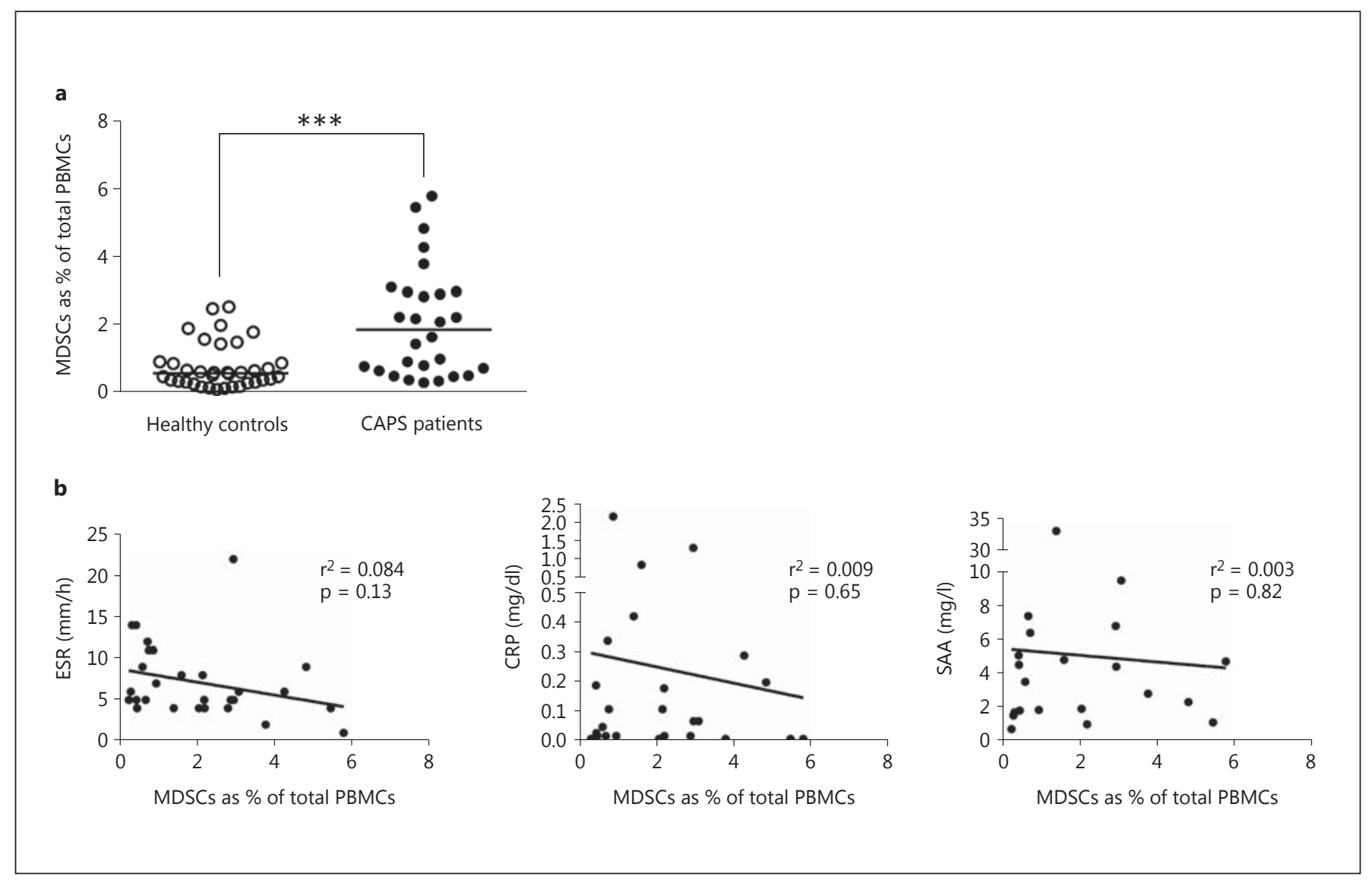

Fig. 2. MDSCs in CAPS patients. a Neutrophilic MDSCs are increased in CAPS patients. Percentages of MDSCs in a CAPS patient cohort $(\mathrm{n}=28)$ were significantly increased compared to healthy age-matched controls $(n=36)$. The depicted data were assessed by flow cytometry and represent means \pm SEM, whereby differences were analyzed by an unpaired t test. ${ }^{* * *} \mathrm{p}<0.001$. b Common laboratory inflammation markers did not correlate with the number of MDSCs. Levels of ESR, CRP, and SAA as common inflammation markers were measured in clinical routine; they did not show a significant correlation with MDSCs in CAPS patients and were mostly within normal limits at the time of blood sampling. Correlation of markers with MDSCs is shown with Spearman's correlation coefficient $r$.
Fig. 3. MDSCs from CAPS patients are suppressive on T cells and monocytes. a-c MDSCs from CAPS patients are able to suppress $\mathrm{T}$-cell proliferation in a dose-dependent manner involving ROS. The suppressive effect of MACS-isolated MDSCs $\left(\mathrm{CD} 6 \mathrm{~b}^{+}\right)$from CAPS patients on $\mathrm{T}$ cells $\left(\mathrm{CD} 4^{+}\right.$and $\mathrm{CD} 8^{+} \mathrm{T}$ cells) was analyzed by coculture of different MDSC-to-target (PBMC) ratios (1:2 and 1: 12) and assessed by CFSE staining and flow cytometry. Shown are representative histograms (a) including a medium control, where PBMCs have been cultured in complete medium only, and the statistics of 3 independent experiments (b); conventional neutrophils (PMNs) did not have any effects on T-cell proliferation. c ROS were blocked by DPI and iNOS by L-NMMA. d, e IFN $\gamma$ and IL-17 secretions are decreased by MDSCs. IFN $\gamma$ (d) and IL-17 (e) secretions in the supernatant were measured in MDSC/PBMC coculture experiments (see a) by ELISA and multiplex cytokine array. f IL- $1 \beta$ secretion by monocytes is decreased by MDSCs. MDSCs $\left(\mathrm{CD}_{6} \mathrm{~b}^{+}\right)$and monocytes $\left(\mathrm{CD} 14^{+}\right)$were isolated by MACS from heparinized blood of CAPS patients and cocultured with or without LPS $(10 \mathrm{ng} / \mathrm{ml})$ in complete medium at $37^{\circ} \mathrm{C}$ and $5 \% \mathrm{CO}_{2}$. After $4 \mathrm{~h}$ of incubation, supernatants were analyzed for IL- $1 \beta \mathrm{lev}$ els with ELISA. Data are shown as means \pm SEM analyzed by a paired t test. ${ }^{*} \mathrm{p}<0.05 ;{ }^{* *} \mathrm{p}<0.01$; $^{* * *} \mathrm{p}<0.001$.

(For figure see next page.) 


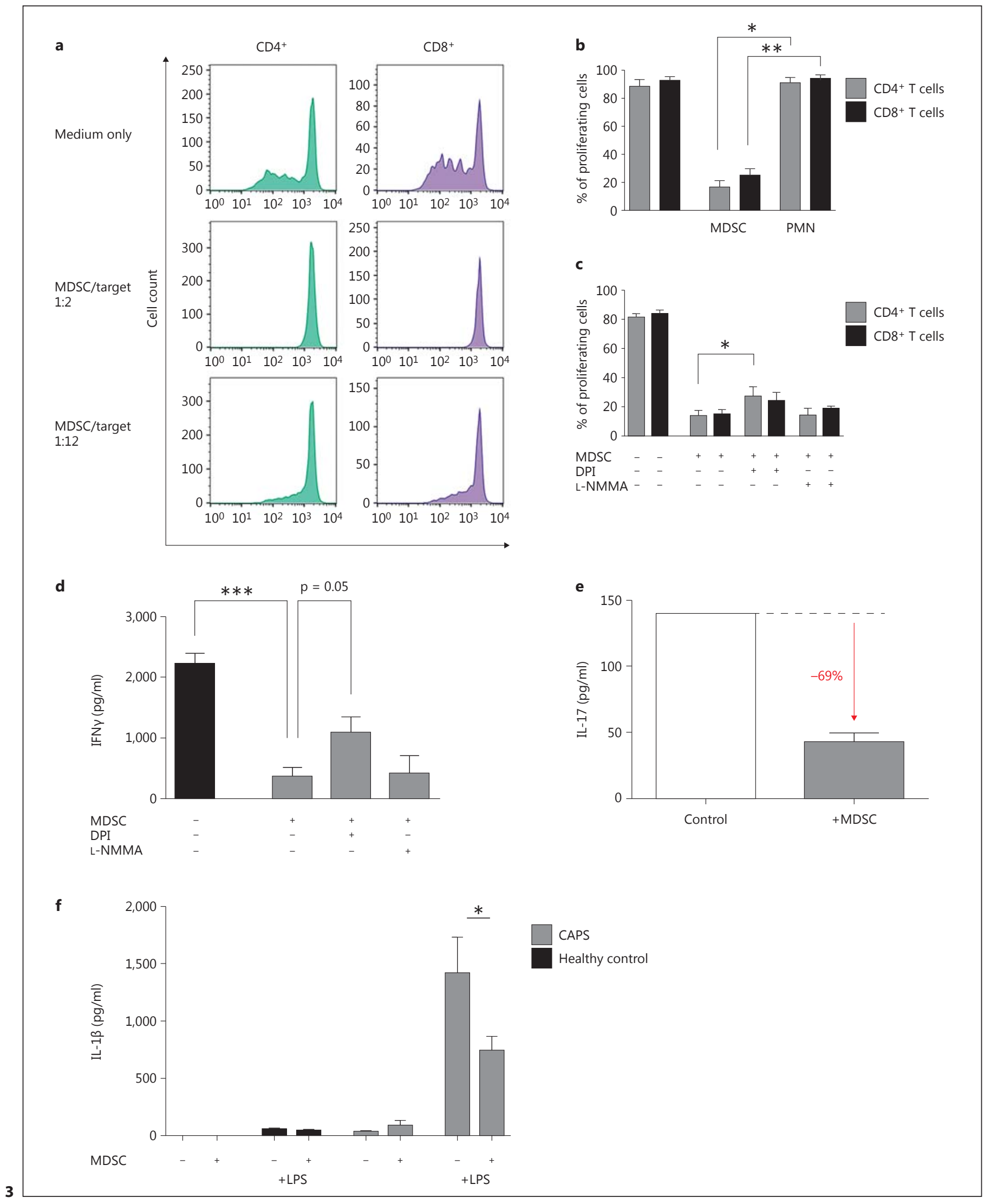




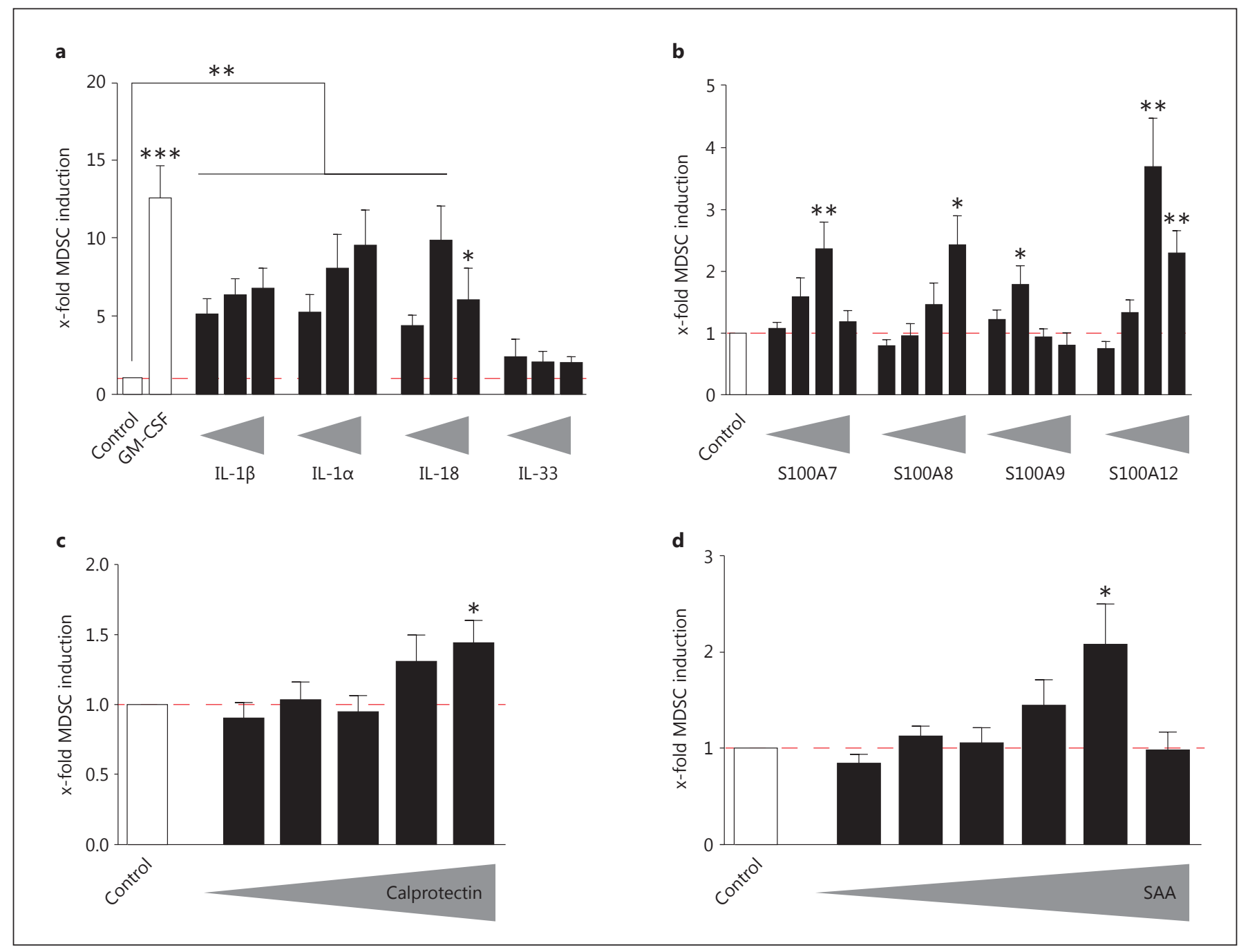

Fig. 4. Inflammasome-dependent IL-1 family cytokines and alarmins induce MDSCs in vitro. a IL- 1 family members IL- $1 \beta$, Il-1 $\alpha$, and IL-18 are able to induce MDSCs. PBMCs were isolated from heparinized fresh blood from healthy donors using Ficoll density gradient sedimentation. MDSCs were induced by incubating PBMCs $\left(5 \times 10^{5} / \mathrm{ml}\right)$ with complete medium only (medium control), $10 \mathrm{ng} / \mathrm{ml} \mathrm{GM-CSF}$ (positive control), or different concentrations $(1 \mathrm{ng} / \mathrm{ml}$ to $1 \mu \mathrm{g} / \mathrm{ml}$ ) of the respective IL-1 family cytokines. MDSCs were determined as $\mathrm{SSC}^{\text {high }} \mathrm{CD} 33^{+} \mathrm{CD} 14^{-}$cells. The number of MDSCs as a percentage of all cells in medium-only cultures (mean 1.69\%; median 1.3\%) were set to 1 -fold for every single experiment. The MDSC induction due to specific stimuli is presented as $\mathrm{x}$-fold compared to medium control (mean \pm SEM), and differences compared to controls were analyzed by a one-sample $\mathrm{t}$ test. b S100 proteins are able to slightly induce MDSCs. General culture conditions were as described under a. S100 proteins
S100A7, S100A8, S100A9, or S100A12 were added in different concentrations ranging from $1 \mathrm{ng} / \mathrm{ml}$ to $1 \mu \mathrm{g} / \mathrm{ml}$. The $\mathrm{x}$-fold induction of MDSCs compared to medium control conditions is depicted as means \pm SEM, and differences were analyzed by a one-sample t test. c Calprotectin is able to induce MDSCs. General culture conditions were as described under a. Calprotectin was added in different concentrations ranging from $1 \mathrm{ng} / \mathrm{ml}$ to $2 \mu \mathrm{g} / \mathrm{ml}$. The $\mathrm{x}-$ fold induction of MDSCs compared to medium control conditions is depicted as means \pm SEM, and differences were analyzed by a one-sample t test. d SAA is able to induce MDSCs. General culture conditions were as described in a. Recombinant hybrid SAA was added in different concentrations ranging from $0.1 \mathrm{ng} / \mathrm{ml}$ to $2 \mu \mathrm{g} /$ $\mathrm{ml}$. The $\mathrm{x}$-fold induction of MDSCs compared to medium control conditions is depicted as means \pm SEM, and differences were analyzed by a one-sample t test. ${ }^{*} \mathrm{p}<0.05$; $^{* *} \mathrm{p}<0.01$; $^{* * *} \mathrm{p}<0.001$. 
MDSCs in CAPS Patients Suppress T-Cell

Proliferation, IFN $\gamma$, and IL-17 Secretion

To test the suppressive function of MDSCs in CAPS patients, we isolated neutrophilic MDSCs utilizing the magnetic bead technique and cocultured these cells together with OKT3- and IL-2-stimulated PBMCs. These experiments using T-cell CFSE labeling demonstrated that CAPS patient-derived neutrophilic MDSCs efficiently suppressed polyclonal T-cell proliferation of both $\mathrm{CD}^{+}$and $\mathrm{CD} 8^{+} \mathrm{T}$-cell subsets in a dose-dependent manner (fig. 3a, b). Conventional neutrophils did not suppress $\mathrm{CD} 4^{+}$or $\mathrm{CD} 8^{+} \mathrm{T}$-cell proliferation. To gain further insights into the mechanisms of T-cell suppression, we blocked ROS (reactive oxygen species) by DPI and NOS (nitrogen oxide synthase) by L-NMMA. These experiments showed that the production of ROS is a main mechanism, but it did not account for the entire suppressive effect (fig. 3c). In parallel with the suppression of T-cell proliferation, IFN $\gamma$ secretion was diminished by MDSCs by a mechanism that also seemed to involve ROS (fig. 3d).

Since IL-17-producing T cells have been previously suggested to play a role in the pathogenesis of CAPS [8, 30], we investigated whether CAPS-isolated neutrophilic MDSCs are capable of modulating IL-17 cytokine production by $\mathrm{CD}^{+} \mathrm{T}$ cells. These studies showed that CAPS patient-derived neutrophilic MDSCs substantially dampened released IL-17 protein (69\% reduction of IL-17 protein; fig. 3e).

\section{MDSCs in CAPS Patients Decrease IL-1 $\beta$ Secretion by Monocytes}

Beyond the already established suppression of T-cell responses we were interested to see whether neutrophilic MDSCs would also influence the IL- $1 \beta$ secretion of monocytes as a cardinal pathogenetic mechanism in CAPS. Our studies demonstrate that the cocultivation of neutrophilic MDSCs with inflammasome-stimulated $\mathrm{CD} 14^{+}$monocytes from CAPS patients led to a significant decrease of IL- $1 \beta$ in the supernatant $(48 \%$ reduction of IL-1 $\beta$; fig. $3 \mathrm{f}$ ). Conventional neutrophils, however, did not show any effect on the IL- $1 \beta$ amount in the supernatant, which argues against an unspecific proteolytic cleavage effect by neutrophils in general (online suppl. fig. S2).

Inflammasome-Dependent IL-1 Family Cytokines and Alarmins Increase MDSCs in vitro

To analyze which factors in CAPS patients might contribute to the generation of MDSCs, we first tested IL-1 cytokine family members on their capacity to induce
MDSC generation in vitro. These studies showed that the IL- 1 cytokine family members IL- $1 \beta$, IL- $1 \alpha$, and IL-18, but not IL-33, efficiently induced MDSCs to a similar extent as the well-established MDSC-inducing protein GMCSF [26] (fig. 4a). S100 proteins, including the S100A8/ A9 heterodimer calprotectin, SAA, and other increased inflammatory proteins in CAPS patients [31] with established effects on the MDSC generation in mice [32-34], elicited an overall slight impact on the MDSC amount in human in vitro cultures (fig. $4 \mathrm{~b}-\mathrm{d}$ ).

\section{Distinct Growth Factors and Chemokines Are \\ Elevated in CAPS Patients}

In the search for further potential MDSC-inducing factors involved in CAPS patients we applied a multiplex cytokine/growth factor array and examined frozen sera from CAPS patients before and after the initiation of an effective anti-IL-1 therapy (fig. 5; online suppl. table 1). These studies revealed that the well-established MDSCinducing factors GM-CSF and vascular endothelial growth factor (VEGF) $[10,26,35]$ were increased in CAPS sera before and still after the initiation of a clinically effective anti-IL-1 therapy (fig. 5b). Furthermore, the fibroblast growth factor (FGF), another growth factor, known to be secreted in a direct NLRP3-dependent manner [36], was increased in CAPS sera. Additionally, we found several chemokines (IL-8, MCP-1, and MIP1a) significantly elevated in CAPS sera even under effective anti-IL-1 therapy (fig. 5c). However, a relation to MDSC induction has not yet been reported for these proteins. When viewed in combination, these studies indicate that IL-1 family cytokines on the one hand and several growth factors on the other hand seem to be involved in the generation of MDSCs in CAPS patients.

\section{IL-1- and GM-CSF-Induced MDSCs Suppress T-Cell} Proliferation and IFN $\gamma$ Release

Finally, we investigated whether MDSCs induced by IL-1 family cytokines and GM-CSF exhibit a similar Tcell suppressive phenotype as ex vivo isolated neutrophilic MDSCs from CAPS patients. The proliferation assays showed that MDSCs induced in vitro with IL-1 $\beta$, Il- $1 \alpha$, or IL-18 are able to suppress T-cell proliferation of both $\mathrm{CD}^{+}$and $\mathrm{CD} 8^{+} \mathrm{T}$ cells in a dose-dependent manner to a similar extent as GM-CSF-induced MDSCs. Results from the IFN $\gamma$ secretion tests also showed a suppressive effect of in-vitro-induced MDSCs on T-cell responses, as secretion of IFN $\gamma$ is markedly reduced upon cocultivation of the two cell types. Collectively, in these experiments we showed that in-vitro-induced MDSCs recapitulated the 
T-cell suppressive characteristics of ex vivo isolated neutrophilic MDSCs from CAPS patients, robustly suppressing both $\mathrm{CD}^{+}$and $\mathrm{CD} 8^{+}$T-cell activities (fig. 6).

\section{Discussion}

Our studies demonstrate for the first time that neutrophilic MDSCs accumulate in a human inflammasomedriven autoinflammatory disease condition. Neutrophilic MDSCs were induced in CAPS patients under anti-IL-1 therapy and dampened inflammatory T-cell and monocytic IL-1 $\beta$ responses. Neutrophilic MDSCs may represent a novel autoregulatory mechanism in inflammatory diseases, which may serve as a future therapeutic target.

Thirty years ago, IL-1RA was identified as an autologous anti-inflammatory mechanism in inflammatory conditions [37]. Later, the recombinant IL-1RA anakinra was successfully used as a targeted therapy in CAPS patients $[38,39]$. In this study, we identified another autologous anti-inflammatory mechanism in CAPS patients, namely neutrophilic MDSCs. With respect to their segmented nuclear morphology, these neutrophilic cells seemed to be rather mature, which is in line with previous reports demonstrating activated mature neutrophils with a suppressive phenotype $[15,25,32,40]$. As mentioned in the introduction, the maturation stage of neutrophilic MDSCs is still a matter of debate in the field. In this paper we follow the definition of neutrophilic/granulocytic MDSCs as a heterogeneous group of T-cell suppressive immune cells with neutrophilic/granulocytic phenotypes without a clear demarcation between immature and mature cells, as discussed in detail elsewhere [18-21]. Compared to conventional neutrophils the neutrophilic MDSCs in our population exhibited increased expression of chemokine receptors CXCR4 and CCR2, as described before $[17,28,29]$. We would like to emphasize that only

Fig. 5. Several growth factors and chemokines are elevated in CAPS patients. a Multiplex cytokine array analysis. Multiplex cytokine array analysis was performed with sera of CAPS patients before $(n=22)$ and 4 weeks after $(n=21)$ the initiation of anti-IL-1 therapy with canakinumab and of healthy controls $(n=5)$ using the Bio-Plex protein multi-array system. The color plot represents $\mathrm{x}$-fold change compared to the median value of the healthy controls (color scale bar on the right). b Growth factors are elevated in CAPS patients. Multiplex cytokine array analysis (see a) revealed the well-established MDSC-inducing factors GM-CSF, VEGF, and FGF to be elevated in CAPS patients before and after quantitative differences in the expression level of chemokine receptors have been identified. To the best of our knowledge, there is still no unique marker for neutrophilic MDSCs in humans.

Neutrophilic MDSCs are known to be suppressive on $\mathrm{T}$ and NK cells. On the other hand, highly inflammatory Th17 cells have been reported to be increased in autoinflammatory diseases/CAPS $[8,30]$. Therefore, the increased MDSCs might be regarded as an autologous feedback mechanism counteracting these enhanced T-cell activities. The immunomodulation of T-cell answers was shown in our in vitro functional studies either by means of proliferation arrest or inhibition of cytokine secretion (IFN $\gamma$ and IL-17). Furthermore, this is the first study to report an effect of MDSCs on the IL- $1 \beta$ production of monocytes. Previously, an influence on dendritic cells has been described [41], but the IL- $1 \beta$ secretion has not been investigated before. The mechanisms leading to the reduction of IL- $1 \beta$ in MDSC/monocyte cocultures might include (1) proteolytic cleavage of IL-1 $\beta$, (2) binding/uptake of IL- $1 \beta$ and (3) direct dampening of the inflammasome activity. We could demonstrate that conventional neutrophils did not have a similar effect on the IL- $1 \beta$ concentration. Dampening the amount of IL- $1 \beta$ directly antagonizes the effect of NLRP3 hyperactivation in CAPS. MDSCs might cooperate with other innate anti-inflammatory mechanisms like IL-1RA to limit excessive inflammation in these patients. Further studies are warranted to clarify the underlying mechanisms of this observation.

According to our in vitro data IL-1-targeted therapy in CAPS patients should decrease MDSC numbers. Unfortunately, we could not analyze fresh patient samples before and after the start of IL-1-targeted therapy, as all CAPS patients were already under anti-IL-1 therapy at study entry. Intriguingly, MDSCs were elevated even under highly effective anti-IL-1 therapy and in patients

the initiation of anti-IL-1 therapy. Data sets are represented as means \pm SEM, and differences were analyzed by the Mann-Whitney test for unpaired or the Wilcoxon test for paired data sets. c Chemokines are elevated in CAPS patients. Multiplex cytokine array analysis (see a) revealed the chemokines MCP-1 and MIP$1 \alpha$ to be elevated in CAPS patients before and after the initiation of anti-IL-1 therapy. IL-8 was significantly increased only before the initiation of anti-IL-1 therapy. Data sets are represented as means \pm SEM, and differences were analyzed by the Mann-Whitney test for unpaired or the Wilcoxon test for paired data sets. $* \mathrm{p}<0.05$.

(For figure see next page.) 


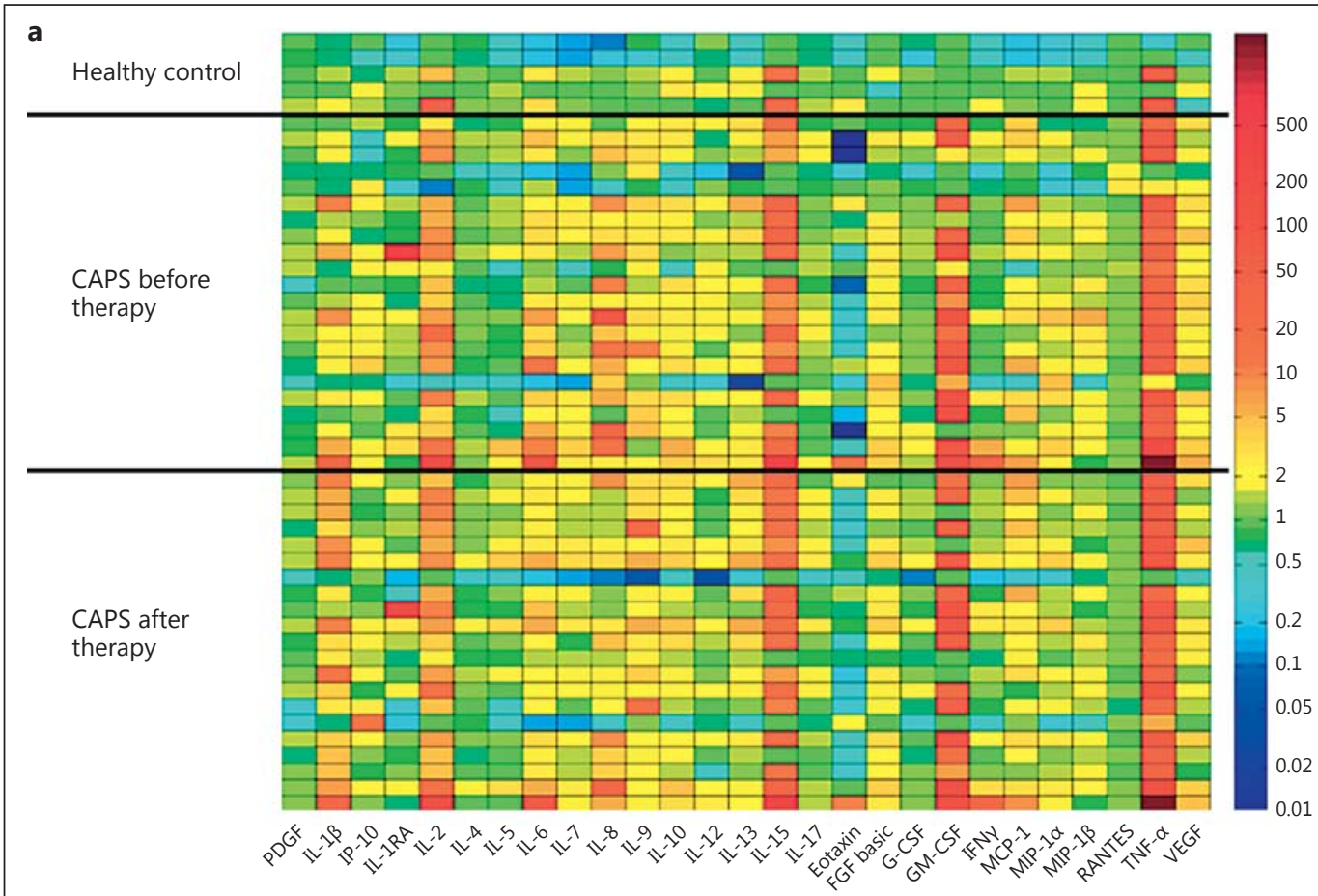

b

$\square$ Healthy control

CAPS before anti-IL-1 $\beta$ therapy

CAPS after anti-IL-1 $\beta$ therapy
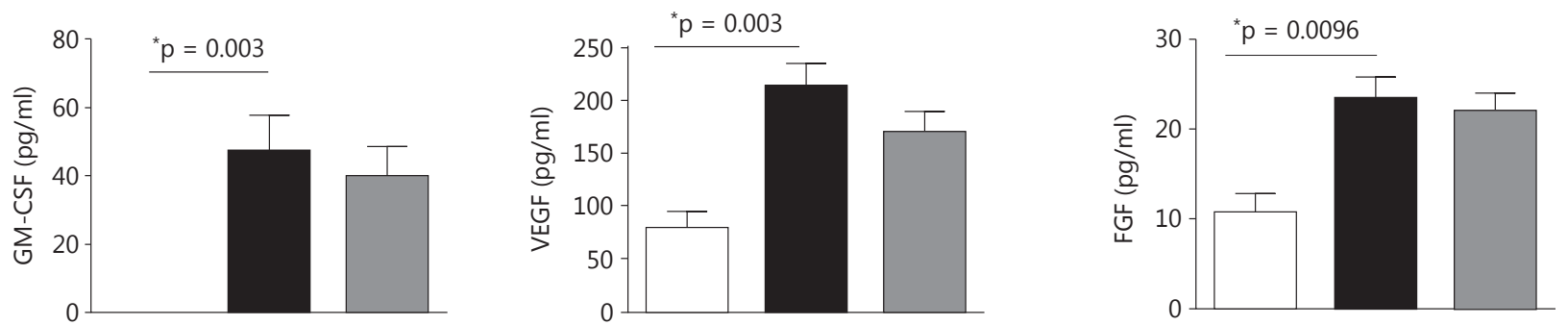

$\square$ Healthy control

CAPS before anti-IL-1 $\beta$ therapy

CAPS after anti-IL-1 $\beta$ therapy
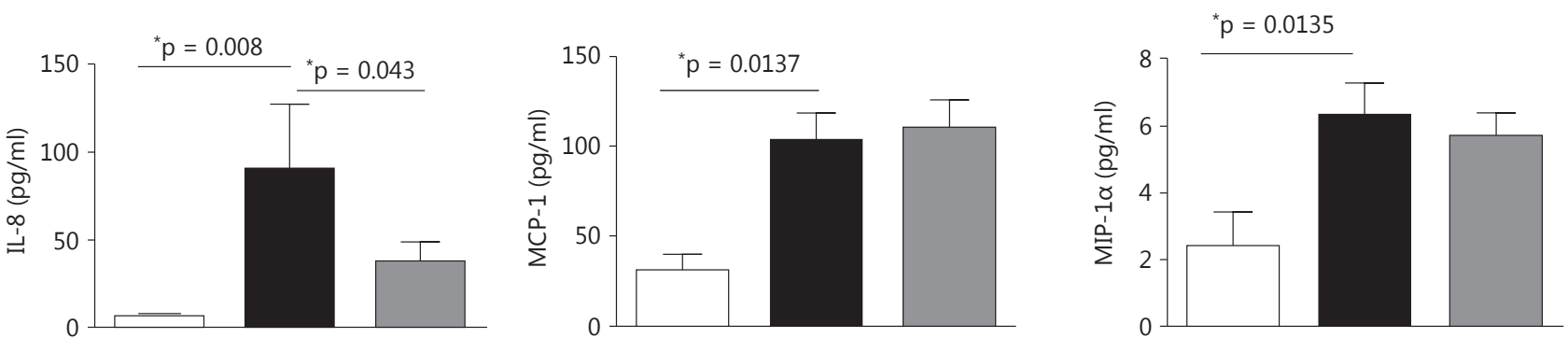

5 
showing clinical remission. The elevated MDSC numbers in patients with clinical remission may point to subclinical inflammatory activities possibly related to NLRP3-dependent factors other than IL- $1 \beta$. It is important to note that these patients suffer from inborn defects of the NLRP3 inflammasome and have never experienced a completely normal inflammatory status. Therefore, clinical remission may be hard to define in these patients. One possible factor in the counter-regulatory feedback loop of MDSCs in autoinflammatory diseases might be SAA, which has a role in MDSC induction (e.g. in bacterial sepsis) [34]. SAA is also commonly elevated in autoinflammatory syndromes and might therefore contribute to the increase of MDSCs in these diseases. In our in vitro experiments SAA led to a slight increase in MDSCs. However, we used a recombinant hybrid SAA which elicits different inflammatory activities compared to the naturally occurring human SAA [42]. To gain further insights into which molecules might be involved in MDSC generation we applied two strategies: (1) testing of established NLRP3-dependent IL-1 family cytokines for their capacity to induce MDSCs in vitro and (2) examination of sera from CAPS patients with a multiplex cytokine/ growth factor array in comparison to healthy controls. The experiments with IL-1 family members exhibited a strong inducing effect on MDSC generation for IL-1 $\beta$, which has been reported previously $[22,26]$. A new finding from our study was, however, that this effect is not restricted to IL- $1 \beta$, but that other IL- 1 family members, particularly IL- $1 \alpha$ and IL-18, had an even higher potency in inducing MDSCs than IL-1 $\beta$. A recent report showed monocytic MDSC induction by IL-18 in mice [24]. These IL-1 family members may contribute to elevated MDSCs in CAPS patients even after effective anti-IL- $1 \beta$ therapy. IL-33, on the other hand, had virtually no influence on MDSC generation in our studies. Analyses of sera from CAPS patients primarily exhibited elevated serum levels for growth factors and chemokines, which has not been reported before. Most of these factors did not decrease under an effective anti-IL-1 $\beta$ therapy, suggesting that these elevations may not depend on IL- $1 \beta$ secretion. For example, FGF secretion has been demonstrated to be NLRP3 dependent, but independent from catalytic caspase- 1 activity and IL-1 [36]. The increased growth factors and chemokines may also point to a subclinical inflammation even under successful anti-IL-1 therapy and, together with the increased number of MDSCs, may become valuable disease biomarkers. Here, larger longitudinal studies are needed for a comprehensive evaluation. A thorough long-term observation of chronic inflammatory changes in CAPS patients is already warranted. This is underscored by the fact that several of these factors have been associated with chronic disease manifestations, like FGF with organ fibrosis [43] and VEGF with arteriosclerosis $[44,45]$.

Remarkably, two of the identified elevated growth factors in CAPS sera, GM-CSF and VEGF, have consistently been reported as MDSC-inducing factors [10, 26, 35]. We and others used GM-CSF as a positive control in MDSC induction assays. Therefore, our study identified several factors that may well contribute to the increased MDSC numbers even under anti-IL-1 therapy. For the moment we can only speculate on the role these cells may have in the chronic disease process. However, $\mathrm{T}$ cells have been shown to be considerably skewed towards highly inflammatory subtypes like Th17 cells in autoinflammatory diseases $[8,30]$. MDSCs as a physiological anti-inflammatory response may counteract this dysregulated activity.

In vivo generation of MDSCs or ex vivo expansion and adoptive transfer may become a future therapeutic strategy in severe cases or in specific complications of autoinflammation not sufficiently responding to conventional therapies. The established application of mesenchymal stem cells in entities like GvHD (graft-versus-host disease) [46] may also point the way for cell-based therapies in certain autoinflammatory disease states. Possible components in this approach, already employed as medical therapies for other indications, might be GM-CSF or
Fig. 6. IL-1 family members increase T-cell suppressive MDSCs in vitro. a MDSCs were generated by incubating PBMCs $\left(5 \times 10^{5} / \mathrm{ml}\right)$ from heparinized fresh blood with GM-CSF $(10 \mathrm{ng} / \mathrm{ml})$ as positive control or IL-1 $\beta$ (10 ng/ml), IL-1 $\alpha$ (100 ng/ml), or IL-18 (100 ng/ $\mathrm{ml})$. After 6 days, MDSCs were isolated using MACS separation and cocultured with PBMCs from healthy donors stained with CFSE in different ratios (1:2 and 1:6). Proliferation was analyzed after 4 days by flow cytometry. For each cytokine at least 3 independent experiments were conducted. Respective histograms are shown. $\mathbf{b}$ The graph shows the percentage (means \pm SEM) of proliferating $\mathrm{CD}^{+}$(upper panel) and $\mathrm{CD}^{+}$(lower panel) T cells without MDSCs (negative control) or in coculture with MDSCs, induced either with GM-CSF (positive control) or the respective IL-1 family members. Differences were analyzed by an unpaired $t$ test. c IFN $\gamma$ secretion by T cells was analyzed via ELISA of supernatants of coculture of MDSCs and T cells (see a). Data sets are represented as means \pm SEM, and differences were analyzed by an unpaired t test. ${ }^{*} \mathrm{p}<0.05{ }^{* *} \mathrm{p}<0.01{ }^{* * *} \mathrm{p}<0.001$.

(For figure see next page.) 


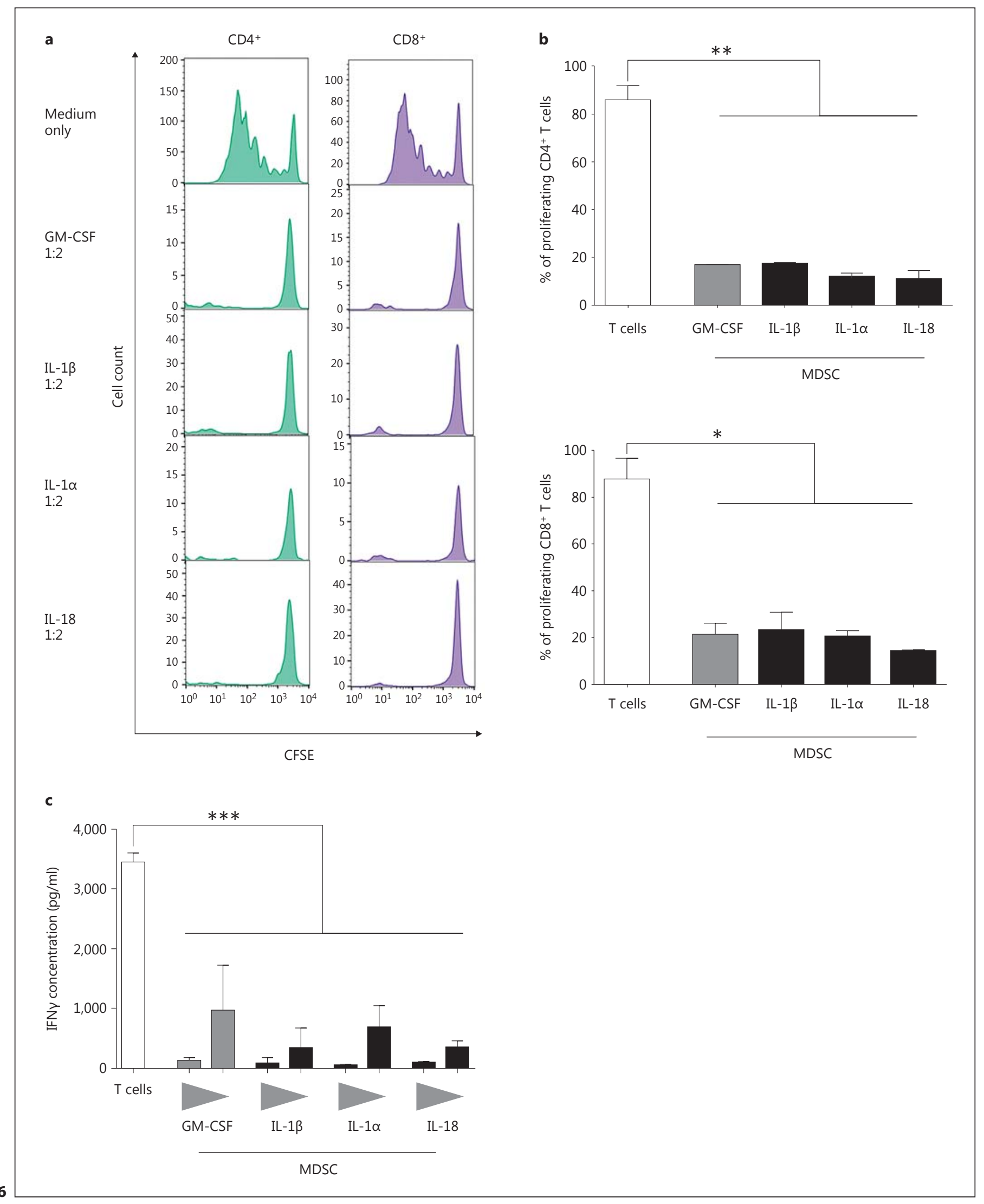


physical therapies like extracorporal photopheresis, which has recently been associated with the induction of MDSCs in GvHD [47].

Beyond these studies, we have preliminary data that the increased percentages of MDSCs are also found in other autoinflammatory diseases, such as TRAPS (tumor necrosis factor receptor-associated periodic syndrome), FMF (familial Mediterranean fever) and PFAPA (periodic fever, aphthous stomatitis, pharyngitis and adenitis; data not shown), and might represent a common mechanism of counter-regulation in autoinflammatory diseases. This could also provide a new rationale for the observed strong periodicity of some of these syndromes, in particular PFAPA [48]. Inflammation (due to multiple reasons, e.g. chronic infections or chronic inflammasome activation) would induce the generation of MDSCs from myeloid progenitor cells in the bone marrow over several days to weeks. These MDSCs would then decrease inflammation, followed by a disappearance of MDSCs over several days due to fading inflammatory stimuli. The disappearance of MDSCs would again allow the rise of inflammation, leading to a new cycle of progenitor cell differentiation.

Taken together, our studies demonstrate that neutrophilic MDSCs are induced in CAPS patients under antiIL-1 therapy and reveal several MDSC-inducing factors in these patients. Increased MDSCs represent a novel autologous anti-inflammatory mechanism in autoinflammatory conditions by limiting both inflammatory T-cell and monocyte responses. MDSCs may serve as a future therapeutic target in autoinflammation.

\section{Acknowledgments}

This study was supported by the German Research Foundation (DFG) Emmy Noether Programme (HA 5274/3-1 to D.H.) and an unrestricted research grant from Novartis to N.R., D.H., and J.K.-D.

\section{References}

1 Cuisset L, Jeru I, Dumont B, Fabre A, Cochet E, Le Bozec J, Delpech M, Amselem S, Touitou I; French CAPS Study Group: Mutations in the autoinflammatory cryopyrin-associated periodic syndrome gene: epidemiological study and lessons from eight years of genetic analysis in France. Ann Rheum Dis 2011;70: 495-499.

-2 Levy R, Gerard L, Kuemmerle-Deschner J, Lachmann HJ, Koné-Paut I, Cantarini L, Woo $\mathrm{P}$, Naselli A, Bader-Meunier B, Insalaco A, AlMayouf SM, Ozen S, Hofer M, Frenkel J, Modesto C, Nikishina I, Schwarz T, Martino S, Meini A, Quartier P, Martini A, Ruperto N, Neven B, Gattorno M; for PRINTO and Eurofever: Phenotypic and genotypic characteristics of cryopyrin-associated periodic syndrome: a series of 136 patients from the Eurofever Registry. Ann Rheum Dis 2015;74: 2043-2049.

3 Hoffman HM, Mueller JL, Broide DH, Wanderer AA, Kolodner RD: Mutation of a new gene encoding a putative pyrin-like protein causes familial cold autoinflammatory syndrome and Muckle-Wells syndrome. Nat Genet 2001;29:301-305.

4 Tassi S, Carta S, Delfino L, Caorsi R, Martini A, Gattorno M, Rubartelli A: Altered redox state of monocytes from cryopyrin-associated periodic syndromes causes accelerated IL- $1 \beta$ secretion. Proc Natl Acad Sci USA 2010;107: 9789-9794.

5 Kastner DL, Aksentijevich I, Goldbach-Mansky R: Autoinflammatory disease reloaded: a clinical perspective. Cell 2010;140:784-790.
6 Mason DR, Beck PL, Muruve DA: Nucleotide-binding oligomerization domain-like receptors and inflammasomes in the pathogenesis of non-microbial inflammation and diseases. J Innate Immun 2012;4:16-30.

7 Ter Haar NM, Oswald M, Jeyaratnam J, Anton J, Barron KS, Brogan PA, Cantarini L, Galeotti C, Grateau G, Hentgen V, Hofer M, Kallinich T, Koné-Paut I, Lachmann HJ, Ozdogan $\mathrm{H}$, Ozen S, Russo R, Simon A, Uziel Y, Wouters C, Feldman BM, Vastert SJ, Wulffraat NM, Benseler SM, Frenkel J, Gattorno M, Kuemmerle-Deschner JB: Recommendations for the management of autoinflammatory diseases. Ann Rheum Dis 2015;74:16361644.

${ }_{8}$ Lasiglie D, Traggiai E, Federici S, Alessio M, Buoncompagni A, Accogli A, Chiesa S, Penco F, Martini A, Gattorno M: Role of IL- $1 \beta$ in the development of human Th17 cells: lesson from NLRP3 mutated patients. PLoS One 2011;6:e20014.

-9 Youn JI, Gabrilovich DI: The biology of myeloid-derived suppressor cells: the blessing and the curse of morphological and functional heterogeneity. Eur J Immunol 2010;40: 2969-2975.

10 Gabrilovich DI, Nagaraj S: Myeloid-derived suppressor cells as regulators of the immune system. Nat Rev Immunol 2009;9:162-174.

-11 Dai J, El Gazzar M, Li GY, Moorman JP, Yao ZQ: Myeloid-derived suppressor cells: paradoxical roles in infection and immunity. J Innate Immun 2015;7:116-126.
12 Ribechini E, Greifenberg V, Sandwick S, Lutz M: Subsets, expansion and activation of myeloid-derived suppressor cells. Med Microbiol Immun 2010;199:273-281.

13 Gabrilovich DI, Bronte V, Chen SH, Colombo MP, Ochoa A, Ostrand-Rosenberg S, Schreiber $\mathrm{H}$ : The terminology issue for myeloid-derived suppressor cells. Cancer Res 2007;67: 425-425.

14 Casbon AJ, Reynaud D, Park C, Khuc E, Gan DD, Schepers K, Passegue E, Werb Z: Invasive breast cancer reprograms early myeloid differentiation in the bone marrow to generate immunosuppressive neutrophils. Proc Natl Acad Sci USA 2015;112:E566-E575.

15 Rodriguez PC, Ernstoff MS, Hernandez CP, Atkins M, Zabaleta J, Sierra RA, Ochoa AC: Arginase I-producing myeloid-derived suppressor cells (MDSC) in renal cell carcinoma are a subpopulation of activated granulocytes. Cancer Res 2009;69:1553-1560.

16 Pillay J, Kamp VM, van Hoffen E, Visser T, Tak T, Lammers JW, Ulfman LH, Leenen LP, Pickkers P, Koenderman L: A subset of neutrophils in human systemic inflammation inhibits T cell responses through Mac-1. J Clin Invest 2012;122:327-336.

17 Brandau S, Trellakis S, Bruderek K, Schmaltz D, Steller G, Elian M, Suttmann H, Schenck M, Welling J, Zabel P, Lang S: Myeloid-derived suppressor cells in the peripheral blood of cancer patients contain a subset of immature neutrophils with impaired migratory properties. J Leukoc Biol 2011;89:311-317. 
18 Pillay J, Tak T, Kamp VM, Koenderman L: Immune suppression by neutrophils and granulocytic myeloid-derived suppressor cells: similarities and differences. Cell $\mathrm{Mol}$ Life Sci 2013;70:3813-3827.

19 Dumitru CA, Moses K, Trellakis S, Lang S, Brandau S: Neutrophils and granulocytic myeloid-derived suppressor cells: immunophenotyping, cell biology and clinical relevance in human oncology. Cancer Immunol Immunother 2012;61:1155-1167.

20 Mantovani A: The growing diversity and spectrum of action of myeloid-derived suppressor cells. Eur J Immunol 2010;40:33173320.

-21 Youn JI, Collazo M, Shalova IN, Biswas SK, Gabrilovich DI: Characterization of the nature of granulocytic myeloid-derived suppressor cells in tumor-bearing mice. J Leukoc Biol 2012;91:167-181.

-22 Elkabets M, Ribeiro VS, Dinarello CA, Ostrand-Rosenberg S, Di Santo JP, Apte RN, Vosshenrich CA: IL- $1 \beta$ regulates a novel myeloid-derived suppressor cell subset that impairs NK cell development and function. Eur J Immunol 2010;40:3347-3357.

-23 van Deventer HW, Burgents JE, Wu QP, Woodford RM, Brickey WJ, Allen IC, McElvania-Tekippe E, Serody JS, Ting JP: The inflammasome component NLRP3 impairs antitumor vaccine by enhancing the accumulation of tumor-associated myeloid-derived suppressor cells. Cancer Res 2010;70:1016110169.

24 Lim HX, Hong HJ, Cho D, Kim TS: IL-18 enhances immunosuppressive responses by promoting differentiation into monocytic myeloid-derived suppressor cells. J Immunol 2014;193:5453-5460.

25 Rieber N, Brand A, Hector A, Graepler-Mainka U, Ost M, Schäfer I, Wecker I, Neri D, Wirth A, Mays L, Zundel S, Fuchs J, Handgretinger R, Stern M, Hogardt M, Döring G, Riethmüller J, Kormann M, Hartl D: Flagellin induces myeloid-derived suppressor cells: implications for pseudomonas aeruginosa infection in cystic fibrosis lung disease. J Immunol 2013; 190:1276-1284.

26 Lechner MG, Liebertz DJ, Epstein AL: Characterization of cytokine-induced myeloid-derived suppressor cells from normal human peripheral blood mononuclear cells. J Immunol 2010;185:2273-2284.

-27 Rieber N, Gavrilov A, Hofer L, Singh A, Oz H, Endres T, Schäfer I, Handgretinger R, Hartl D, Kuemmerle-Deschner J: A functional inflammasome activation assay differentiates patients with pathogenic NLRP3 mutations and symptomatic patients with low penetrance variants. Clin Immunol 2015;157:5664.

28 Obermajer N, Muthuswamy R, Odunsi K, Edwards RP, Kalinski P: $\mathrm{PGE}_{2}$-induced CXCL12 production and CXCR4 expression controls the accumulation of human MDSCs in ovarian cancer environment. Cancer Res 2011;71: 7463-7470.
29 Chun E, Lavoie S, Michaud M, Gallini CA, Kim J, Soucy G, Odze R, Glickman JN, Garrett WS: CCL2 promotes colorectal carcinogenesis by enhancing polymorphonuclear myeloid-derived suppressor cell population and function. Cell Rep 2015;12:244-257.

30 Meng G, Zhang F, Fuss I, Kitani A, Strober W: A mutation in the Nlrp3 gene causing inflammasome hyperactivation potentiates Th17 cell-dominant immune responses. Immunity 2009;30:860-874.

31 Wittkowski H, Kuemmerle-Deschner JB, Austermann J, Holzinger D, Goldbach-Mansky R, Gramlich K, Lohse P, Jung T, Roth J, Benseler SM, Foell D: MRP8 and MRP14, phagocyte-specific danger signals, are sensitive biomarkers of disease activity in cryopyrin-associated periodic syndromes. Ann Rheum Dis 2011;70:2075-2081.

- 32 Sinha P, Okoro C, Foell D, Freeze HH, Ostrand-Rosenberg S, Srikrishna G: Proinflammatory S100 proteins regulate the accumulation of myeloid-derived suppressor cells. J Immunol 2008;181:4666-4675.

33 Cheng P, Corzo CA, Luetteke N, Yu B, Nagaraj S, Bui MM, Ortiz M, Nacken W, Sorg C, Vogl T, Roth J, Gabrilovich DI: Inhibition of dendritic cell differentiation and accumulation of myeloid-derived suppressor cells in cancer is regulated by S100A9 protein. J Exp Med 2008;205:2235-2249.

-34 Sander LE, Sackett SD, Dierssen U, Beraza N, Linke RP, Müller M, Blander JM, Tacke F, Trautwein C: Hepatic acute-phase proteins control innate immune responses during infection by promoting myeloid-derived suppressor cell function. J Exp Med 2010;207: 1453-1464.

-35 Dolcetti L, Peranzoni E, Ugel S, Marigo I, Fernandez Gomez A, Mesa C, Geilich M, Winkels G, Traggiai E, Casati A, Grassi F, Bronte V: Hierarchy of immunosuppressive strength among myeloid-derived suppressor cell subsets is determined by GM-CSF. Eur J Immunol 2010;40:22-35.

36 Keller M, Ruegg A, Werner S, Beer HD: Active caspase- 1 is a regulator of unconventional protein secretion. Cell 2008;132:818-831.

37 Liao Z, Grimshaw RS, Rosenstreich DL: Identification of a specific interleukin 1 inhibitor in the urine of febrile patients. J Exp Med 1984;159:126-136.

38 Dinarello CA, van der Meer JW: Treating inflammation by blocking interleukin-1 in humans. Semin Immunol 2013;25:469-484.

-39 Kuemmerle-Deschner JB, Tyrrell PN, Koetter I, Wittkowski H, Bialkowski A, Tzaribachey N, Lohse P, Koitchev A, Deuter C, Foell D, Benseler SM: Efficacy and safety of anakinra therapy in pediatric and adult patients with the autoinflammatory Muckle-Wells syndrome. Arthritis Rheum 2011;63:840-849.
0 Schmielau J, Finn OJ: Activated granulocytes and granulocyte-derived hydrogen peroxide are the underlying mechanism of suppression of T-cell function in advanced cancer patients. Cancer Res 2001;61:4756-4760.

-41 Greifenberg V, Ribechini E, Rössner S, Lutz MB: Myeloid-derived suppressor cell activation by combined LPS and IFN- $\gamma$ treatment impairs DC development. Eur J Immunol 2009;39:2865-2876

42 Björkman L, Raynes JG, Shah C, Karlsson A, Dahlgren C, Bylund J: The proinflammatory activity of recombinant serum amyloid a is not shared by the endogenous protein in the circulation. Arthritis Rheum 2010;62:16601665.

43 Strutz F, Zeisberg M, Hemmerlein B, Sattler B, Hummel K, Becker V, Müller GA: Basic fibroblast growth factor expression is increased in human renal fibrogenesis and may mediate autocrine fibroblast proliferation. Kidney Int 2000;57:1521-1538.

44 Moulton KS, Vakili K, Zurakowski D, Soliman M, Butterfield C, Sylvin E, Lo KM, Gillies S, Javaherian K, Folkman J: Inhibition of plaque neovascularization reduces macrophage accumulation and progression of advanced atherosclerosis. Proc Natl Acad Sci USA 2003;100:4736-4741.

45 Celletti FL, Waugh JM, Amabile PG, Brendolan A, Hilfiker PR, Dake MD: Vascular endothelial growth factor enhances atherosclerotic plaque progression. Nat Med 2001;7: 425-429.

46 Le Blanc K, Frassoni F, Ball L, Locatelli F, Roelofs H, Lewis I, Lanino E, Sundberg B, Bernardo ME, Remberger M, Dini G, Egeler RM, Bacigalupo A, Fibbe W, Ringden O; Developmental Committee of the European Group for Blood and Marrow Transplantation: Mesenchymal stem cells for treatment of steroidresistant, severe, acute graft-versus-host disease: A phase II study. Lancet 2008;371:15791586.

47 Rieber N, Wecker I, Neri D, Fuchs K, Schäfer I, Brand A, Pfeiffer M, Lang P, Bethge W, Amon O, Handgretinger R, Hartl D: Extracorporeal photopheresis increases neutrophilic myeloid-derived suppressor cells in patients with GvHD. Bone Marrow Transplant 2014;49:545-552.

48 Stojanov S, Lapidus S, Chitkara P, Feder H, Salazar JC, Fleisher TA, Brown MR, Edwards KM, Ward MM, Colbert RA, Sun HW, Wood GM, Barham BK, Jones A, Aksentijevich I, Goldbach-Mansky R, Athreya B, Barron KS, Kastner DL: Periodic fever, aphthous stomatitis, pharyngitis, and adenitis (PFAPA) is a disorder of innate immunity and Th1 activation responsive to IL-1 blockade. Proc Natl Acad Sci USA 2011;108: 7148-7153. 